Reprod. Nutr. Dévelop., 1987, 27 (1 A), 77-87.

\title{
Effect of feed intake level in late gestation on arterial blood concentrations of energy substrates, insulin and glucagon in the chronically catheterized gilt
}

\author{
C. SIMOES NUNES, P. H. DUÉE (*) (1), J. P. PÉGORIER (*), A. RÉRAT
}

with the technical assistance of Georgette BRACHET, M. BONNEAU and F. COINTEPAS

Laboratoire de Physiologie de la Nutrition,

I.N.R.A., 78350 Jouy-en-Josas, France.

(*) Centre de Recherches sur la Nutrition,

C.N.R.S., 9, rue J. Hetzel, 92190 Meudon-Bellevue.

Summary. The aim of the present work was to study, in the unstressed catheterized gilt, the effect of pregnancy on arterial substrate and pancreatic hormone concentrations in relation to the feed intake level. The experiments were performed on 14 pregnant gilts during the last month of gestation and 5 non pregnant gilts after cannulation of one carotid artery. Blood samples have been collected regularly after an overnight fast.

After catheterization of the pregnant gilt, a 4 day-period is required to obtain steadystate conditions. As compared with non-pregnant animals fed on the same standard conditions (i.e. $2 \mathrm{~kg} / \mathrm{d}$ : crude protein : $130 \mathrm{~g} / \mathrm{kg}$; digestible energy : $12.8 \mathrm{MJDE} / \mathrm{kg}$ ), pregnant gilts exhibit similar and constant blood glucose, lactate, ketone body and plasma free fatty acid concentrations. By contrast, blood alanine concentration progressively increases.

A reduction of the feed intake level by $40 \%$ does not modify the blood glucose concentrations but leads to reduce blood lactate and alanine concentrations. On the contrary, plasma free fatty acid levels rise progressively with a limited increase in blood ketone body concentrations.

While plasma glucagon concentrations are constant whatever the physiological state or the feed intake level, plasma insulin levels progressively decrease in the pregnant gilt.

These data are discussed to display some aspects of the adaptation of the maternal metabolism in the gilt in late gestation.

\section{Introduction.}

In mammalian species, gestation may represent a substantial challenge to maternal nutrition and metabolism. Nevertheless, in pig production, the recommanded feed intake level during gestation is limited to $45-50 \%$ of the voluntary feed intake (Friend, 1971). Despite this reduced nutrient intake, a lot of experimentations have focused on the existence of a significant maternal weight

(1) Reprint requests : P. H. Duée, Centre de Recherches sur la Nutrition, C.N.R.S., 9, rue Jules Hetzel, 92190 Meudon-Bellevue, France. 
gain, as high as the weight gain of non pregnant pigs kept in the same conditions (Elsley et al., 1966 ; Etienne, 1979 ; Shields and Mahan, 1983). Furthermore, in the case of adult sows, this maternal weight gain is higher than the corresponding weight gain of non pregnant pigs (Salmon-Legagneur, 1965 ; Heap and Lodge, 1967).

In contrast, there is some discrepancy between the different results on maternal body composition at parturition. Maternal body protein, unlike body fat, seems little affected during gestation, which could reflect the metabolic adjustments during this period (Lodge, Friend and Wolynetz, 1979 ; De Wilde, 1980a and b). Nevertheless, the protein intake level represents a determinant factor in the deposition of protein and fat in maternal tissues (Duée et al., 1983). However, even in the case of high intake of energy $(30 \mathrm{MJME} / \mathrm{d})$ and protein $(400 \mathrm{~g} / \mathrm{d})$, protein and fat accretion in maternal tissues without the reproductive component (uterus, mammary region) becomes limited in late pregnancy (Close, Noblet and Heavens, 1985), which suggests a metabolic change from an anabolic to a catabolic state before parturition in the gilt.

In order to provide further information about these metabolic changes in late pregnancy, an experimentation has been carried out on the variations of arterial blood concentrations of energy substrates, insulin and glucagon in the well-fed gilt during the last month of pregnancy. Since a reduced feed intake decreases the energy retention in maternal tissues (Close, Noblet and Heavens, 1985), these arterial blood concentrations have been compared with those obtained after a marked reduction of the feed intake level.

\section{Material and methods.}

Animals and diet. - The experiments were performed on 19 gilts of the Large White breed. At the second oestrus period (body weight : $115 \pm 2 \mathrm{~kg}$ ), fourteen gilts were mated and five not, housed in individual pens and fed on a standard diet based on corn, soybean meal and alfalfa meal (crude protein : $130 \mathrm{~g} / \mathrm{kg}$; digestible energy : $12.8 \mathrm{MJDE} / \mathrm{kg}$ ) at a level of $2 \mathrm{~kg} / \mathrm{d}$.

Surgery. - On day 75 of pregnancy or after a similar period for the non pregnant gilts, carotid artery was cannulated after a $24 \mathrm{~h}$-period of fasting. Gilts were submitted to general anaesthesia by inhalation of halothane $13 \%$; I.C.I. Pharma, Enghien, France). Under aseptic conditions, skin and subcutaneous connectivemuscular tissues were incised parallel to the trachea. Carotid artery was disengaged by clean dissection of neck muscles and perivascular tissues. Twenty $\mathrm{cm}$ of a $150 \mathrm{~cm}$ polyethylene catheter (inner diameter: $1.77 \mathrm{~mm}$; outer diameter : $2.80 \mathrm{~mm}$ ) were inserted into the right carotid artery through a transversal incision of the vessel and the catheter was fixed by two ligatures. The distal end of the catheter was exteriorized at the mid-lateral neck region.

Experimental design. - After surgery, gilts were housed in individual cages and received the same diet at a level of $2 \mathrm{~kg} / \mathrm{d}$ during a 7 day-period. Then the population of pregnant gilts was divided in two groups differing only with the feed 
intake level, i.e., 2 or $1.2 \mathrm{~kg} / \mathrm{d}$, until the end of pregnancy. Each non-pregnant gilt received successively the two feed intake levels $(2$ and then $1.2 \mathrm{~kg} / \mathrm{d})$ during two 12 day-periods without lag period. Nevertheless blood samplings in the second period were performed 3 to 4 days after the nutritional change.

Arterial blood sampling. - Blood samples were drawn just after surgery (under anaesthesia) and each morning after an overnight fast during the initial 7 dayperiod. Thereafter blood was collected every three days after an overnight fast until parturition. An aliquot of whole blood was immediately deproteinized in icecold $6 \%(\mathrm{v} / \mathrm{v})$ perchloric acid, and glucose and acetoacetate were assayed within $24 \mathrm{~h}$. The remaining perchloric acid filtrates and plasma obtained after centrifugation at $4{ }^{\circ} \mathrm{C}$ were stored at $-20^{\circ} \mathrm{C}$ until analysis of other blood metabolites, plasma free fatty acids, insulin and glucagon.

Analysis. - Glucose, lactate, acetoacetate, 3-hydroxybutyrate and alanine were determined in the neutralized extract by standard enzymic technique (Bergmeyer, 1974). Plasma free fatty acids were measured by a radiochemical microtechnique (Ho, 1970). Plasma insulin and glucagon were determined by radioimmunoassays as previously described by Girard et al. (1973). Glucagon was assayed by using antibody $30 \mathrm{~K}$ supplied by $\mathrm{Dr}$. R. H. Unger (Dallas, USA) which is considered as specific for pancreatic glucagon. All enzymes and coenzymes were obtained from Boehringer (Meylan, Frànce).

Statistical ana/ysis. - Results are expressed as means with their standard errors. Statistical analyses were performed using Student's unpaired $t$ test to establish the significance of changes in the parameters studied.

\section{Results.}

On the day of surgery, the mean live weight of pregnant gilts was $144 \pm 6 \mathrm{~kg}$ which corresponded to a weight gain of $29 \pm 3 \mathrm{~kg}$ during the first 75 days of pregnancy. Catheterized pregnant gilts restored the fixed level of feed intake $(2 \mathrm{~kg} / \mathrm{d})$ within two days after surgery.

Blood concentrations of energy substrates and insulin after surgery. - In table 1 are represented the post-surgical evolution of arterial concentrations of blood glucose, lactate, alanine, total ketone bodies (as sum of acetoacetate and 3-hydroxybutyrate), plasma free fatty acids and insulin. When the various concentrations of blood substrates and insulin were compared with the values obtained at day 7 after surgery, the main differences occurred within the first two days. Under anaesthesia (day 0), blood alanine and, to a lesser extent, blood glucose increased while plasma insulin was low. This situation was rapidly reversed the first day after surgery : the blood concentrations of glucose, lactate and alanine were low concomitantly with a depressed plasma level of insulin. On the contrary, the blood concentration of total ketone bodies increased without any modification of plasma free fatty acids. The blood concentration of total ketone bodies remained high the second day after surgery but blood concentrations of glucose, lactate and insulin reached values statistically not different from those obtained 


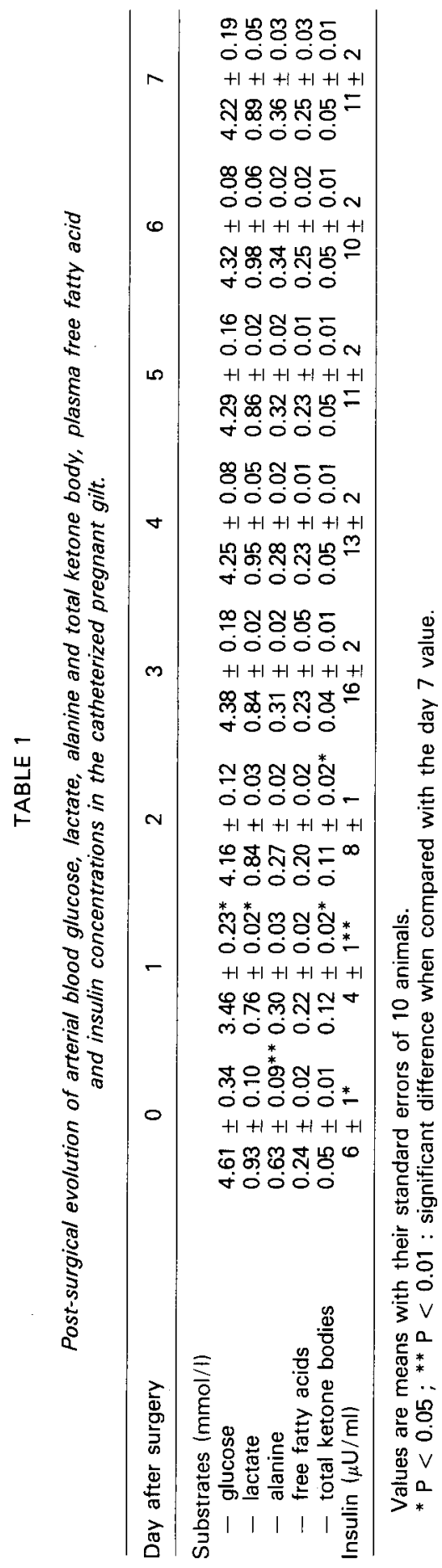


day 7 after surgery. From the fourth day after surgery, the blood concentrations of energy substrates and insulin became steady.

Effects of stage of pregnancy and feed intake level. - After this 7 dayperiod, the population of pregnant gilts was divided in two groups, according to the feed intake level. During the last month of pregnancy the reduction of the feed intake level significantly decreased the live weight gain of the pregnant gilts : $13.2 \pm 2.7 \mathrm{~kg}$ vs $5.0 \pm 1.8 \mathrm{~kg}$. Nevertheless the litter size (mean value : $8.7 \pm 0.9$ piglets) and the mean live weight (mean value : $1.10 \pm 0.11 \mathrm{~kg}$ ) were unaffected by the feed intake level during late pregnancy.

Data on blood concentrations of energy substrates and insulin had been pooled into three classes $(85-95 ; 95-105 ; 105-115)$ according to the day of pregnancy and compared with the respective concentration measured in the non-pregnant gilts (tables 2 and 3 ).

During this period, blood glucose remained constant whatever the physiological state (pregnant vs non-pregnant) or the feed intake level. By contrast, plasma insulin level progressively decreased in the pregnant gilt. As a consequence, the concentration of plasma insulin became lower before parturition than in the nonpregnant gilt (table 2).

During the last month of pregnancy, the concentrations of blood lactate (table 2), total ketone bodies and plasma free fatty acids (table 3) also remained constant and similar to the non-pregnant group. Opposite to that, the concentration of blood alanine rose gradually in the pregnant gilt. These concentrations depended upon the nutritional conditions. With a reduced feed intake level, blood lactate and, to a lesser extent, blood alanine were lower than the corresponding concentrations of well-fed pregnant gilts ; plasma free fatty acids increased progressively and blood ketone bodies were two-fold higher in the restricted group than in the control group.

At last, the concentration of plasma glucagon after an overnight fast was not subject to an effect of the stage of pregnancy or to the reduction of the feed intake level (control group : $246 \pm 14 \mathrm{pg} / \mathrm{ml}$; restricted group : $270 \pm 20 \mathrm{pg} / \mathrm{ml}$ ).

\section{Discussion.}

The major aim of the present work was to study, in the unstressed catheterized gilt, the effect of pregnancy on arterial substrate and pancreatic hormone concentrations in relation to the feed intake level. Longitudinal determination of arterial metabolite concentrations is indicative of the metabolic state of animals. Furthermore, blood sampling after an overnight fast allows to limit the importance of the postprandial influx of exogenous nutrients in the portal vein, as suggested by the absorption kinetics of glucose and amino acids during the digestion of a meal in the pig (Rérat, 1982). Until now, such a study was partially performed in acute conditions from venous blood sampling (Ruiz, Ewan and Speer, 1971; Atinmo, Pond and Barnes, 1974). 


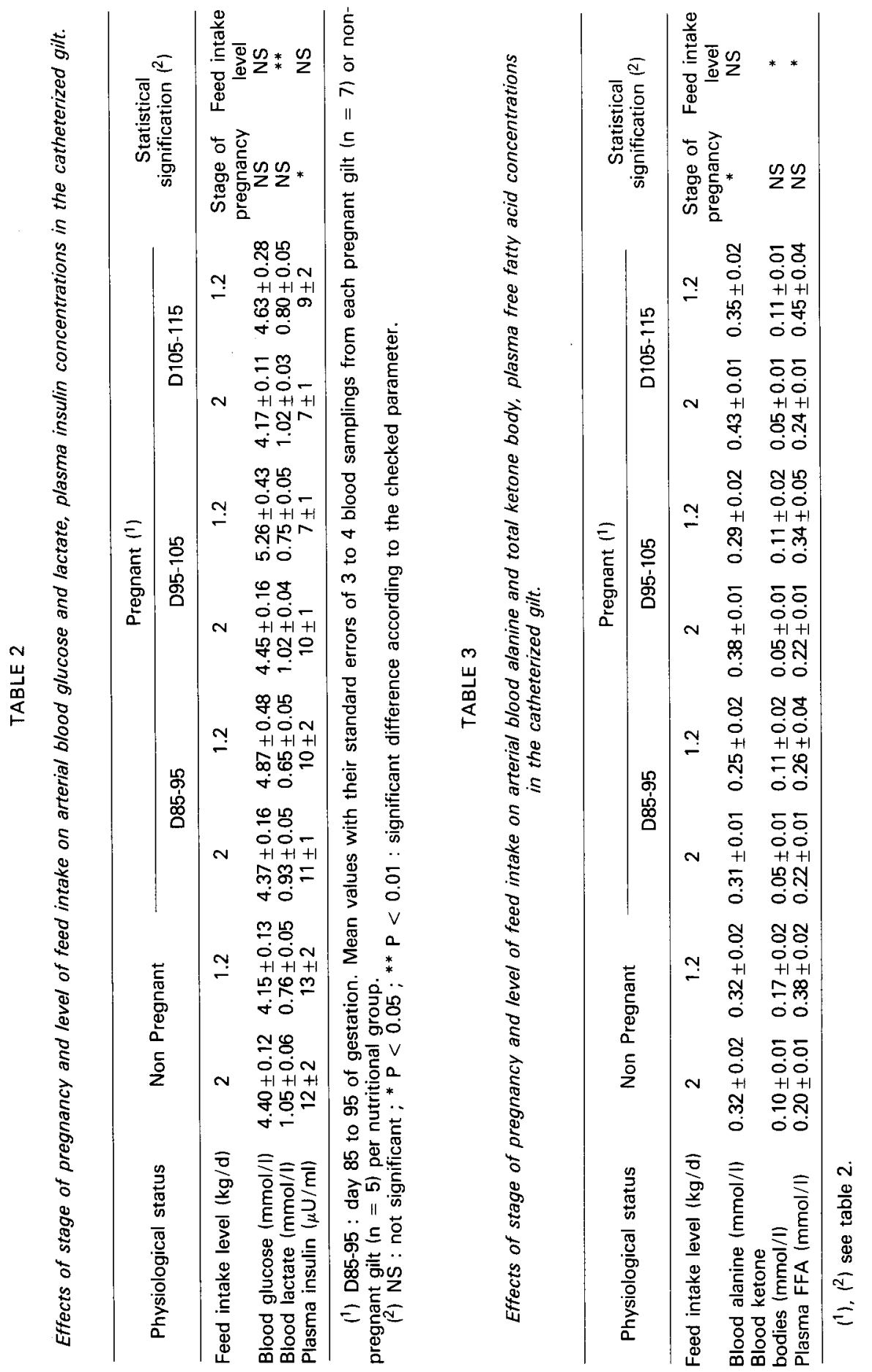


The first aspect of this study was to assess the impact of anaesthesia and surgical stress on the concentrations of blood metabolites and plasma insulin. Blood glucose, alanine and plasma insulin concentrations were altered by the surgical and anaesthetic stress. On the operative day, glucose concentration slightly increases while plasma insulin is low. These changes could be attributed to the effect of halothane on the glucose metabolism, as demonstrated in rats (Aynsley-Green, Biebuyck and Alberti, 1973; Halter and Pflug, 1980). Furthermore, it is well established that surgery or severe trauma induces deep modifications of nitrogen metabolism (O'Keefe, Sender and James, 1974) which could explain a concomitant increase in the blood alanine concentration. Within the first postoperative day, the drop in glucose, alanine concentrations while plasma insulin remains low, probably results from an extended period of starvation which is suppressed $48 \mathrm{~h}$ after surgery when the preoperative feed intake level is restored.

Surprisingly, plasma free fatty acid concentrations do not exhibit marked changes during the experimental study, suggesting a lack of lipid mobilization after surgery and following a short fasting period in the pregnant pig. Opposite data have been obtained in pregnant guinea-pig (Sparks et al., 1981), in human after major surgery (Göschke et al., 1978) or in growing pig within few hours after feed removal (Wangsness et al., 1981). By contrast, the low ketonemia observed is consistent with a defect in hepatic fatty acid oxidation demonstrated in the young pig (Pégorier et al., 1983).

Stable concentrations of blood metabolites are found after the first postoperative day but later concerning plasma insulin. This result indicates that a 4 day-period is required to obtain steady-state conditions after catheterization of the pregnant gilt.

The second aspect of the present study dealt with the effects of gestation on blood metabolite and pancreatic hormone concentrations. As compared with nonpregnant animals fed under the same conditions, pregnant gilts exhibit a similar and constant blood glucose concentration. This result is in good agreement with previous observation (Anderson and Dunseth, 1978) but conflicts with data obtained in acute conditions (Ruiz, Ewan and Speer, 1971 ; Atinmo, Pond and Barnes, 1974). This feature supposes the maintenance of glucose homeostasis in the pregnant gilt which is primordial as glucose represents the main energetic substrate for the foetus (Battaglia and Meschia, 1978). In other laboratory species, blood glucose concentration progressively decreases in late gestation (guinea pig : Sparks et al., 1981 ; rabbit : Gilbert et al., 1984) or remains constant but lower than in non-pregnant animals (rat : Gilbert and Pégorier, 1981). In late human pregnancy, following an overnight fast, blood glucose level is slightly lower than in the non-pregnant state (Phelps, Metzger and Freinkel, 1981), Circulating substrate concentrations alone do not permit to explain such metabolic discrepancies between species; nevertheless several factors could be involved: (1) the total fetal mass produced as compared with the maternal weight, (2) the gestation length, (3) the relative food intake level. In the pig, total fetal mass represents almost $10 \%$ of the maternal pre-pregnancy weight for a large gestation length of 114 days. In other species except for human, total fetal 
mass corresponds to a higher percentage of the maternal weight for a shorter gestation length which, in turn, increases the nutritional demand for fetal growth.

In the pregnant pig, there are several ways to sustain a normal glycemia over the last month of gestation. Firstly, while blood lactate concentration remains constant, blood alanine concentration progressively increases, thus providing an enhanced availability of gluconeogenic substrates. Such a rise has been previously shown in the rat (Gilbert and Pégorier, 1981). As demonstrated in human, a close relationship has been established between circulating alanine concentrations and the alanine synthesis rate (Yang et al., 1986). The major sites of alanine production are muscle and the gut. Even if the alanine release in the portal vein is not completely suppressed after an overnight fasting (Rérat et al., 1977), it is doubtful that gut represents an important site of alanine production. If these data can be extended to the pregnant pig, the increase in arterial alanine could be ascribed to an enhanced alanine de novo synthesis in the muscle. Whether this increased alanine synthesis corresponds to a faster recycling of glucose $C$ atoms or a higher protein breakdown needs further examination. Nevertheless a concomitant rise in blood glutamine level observed in late gestation (Duée et al., 1983) does not rule out the last hypothesis. Secondly, the progressive decrease in the circulating insulin concentration, with a constant plasma glucagon level, is appropriate to stimulate the hepatic glucose production. Furthermore, data from preliminary experiments (Duée, Simoes Nunes and Rérat, unpublished results) and from glucose tolerance tests (George et al., 1978) suggest a decreased insulin sensitivity for the gilt in late gestation. As demonstrated in the rat (Leturque et al., 1984), insulin resistance corresponds to a major characteristic of the maternal adaptation in late gestation which could promote a diversion of glucose from peripheral tissues towards the gravid uterus.

The present study fails to show a marked rise of free fatty acid level in late gestation as previously noticed in acute conditions of blood sampling (Ruiz, Ewan and Speer, 1971 ; Atinmo, Pond and Barnes, 1974). This metabolic situation agrees with data obtained on guinea-pig (Sparks et al., 1981) or rabbit (Gilbert et al., 1984) but differs with observations made on rat (Gilbert and Pégorier, 1981) or in human pregnancy (Kalkhoff, Kissebah and Kim, 1978). If plasma free fatty acid concentrations are assumed to provide a valuable index of lipid mobilization, this result suggests that a lower fat content in maternal body composition at term (Salmon-Legagneur, 1965 ; De Wilde, 1980b; Duée et al., 1983 ; Close, Noblet and Heavens, 1985) does not arise from fat mobilization during the last month of gestation but from a lower lipogenic capacity of the adipose tissue as previously shown by Duée et al. (1983).

The last goal of this study was to observe the effects of a reduced feed intake level on circulating substrate concentrations. A reduction of the feed intake level by $40 \%$ does not modify the fetal growth but leads to suppress the maternal weight gain. In this case, pregnant and non-pregnant gilts maintain a normal blood glucose concentration. Concomitantly the drop in blood lactate and alanine concentrations and a progressive rise of the plasma free fatty acid levels suggest an intense lipid mobilization and a decreased glucose oxidation in peripheral tissues owing to an enhanced fatty acid oxidation. 
In conclusion, this study underlines some metabolic characteristics of the pregnant pig during the last month of pregnancy. The maintenance of a normal glycemia after an overnight fast, whatever the nutritional conditions, does represent a species-specific feature. The demand for an exponential fetal growth during this period induces maternal metabolic changes depending on the feed intake level: (1) a gradual increase of the circulating alanine concentration suggesting an alteration of the muscular protein metabolism. (2) a gradual fat mobilization only in the case of a reduced feed intake level.

Reçu en septembre 1986.

Accepté en novembre 1986.

Acknowledgements. - The authors thank Isabelle Coquelet for her careful preparation of the manuscript.

Résumé. Effet du niveau d'alimentation sur les concentrations artérielles de substrats énergétiques, d'insuline et de glucagon chez la truie cathétérisée, en fin de gestation.

L'étude des variations des concentrations en glucose, lactate, alanine, acides gras non estérifiés, corps cétoniques, insuline et glucagon a été entreprise sur 14 truies gravides durant le dernier mois de gestation et sur 5 truies vierges. Les animaux étaient porteurs d'un cathéter carotidien. L'effet des conditions opératoires et d'une réduction du niveau d'alimentation sur les concentrations des substrats énergétiques et des hormones pancréatiques mesurées après une nuit de jeûne a été considéré.

La première partie de l'expérience a montré qu'un délai de 4 jours après la pose du cathéter est nécessaire pour obtenir un état d'équilibre stationnaire. La seconde partie de l'expérience a montré, dans des conditions normales d'alimentation $12 \mathrm{~kg} / \mathrm{j}$ d'un aliment à $13 \%$ de protéines et de 12,8 MJ d'énergie digestible par $\mathrm{kg}$ ), que les concentrations en glucose, lactate, acides gras et corps cétoniques étaient similaires chez l'animal gravide ou non gravide, quel que soit le stade de gestation. En revanche, la concentration artérielle en alanine augmente progressivement chez la truie gravide.

Lorsque l'apport alimentaire est réduit $(1,2 \mathrm{~kg} / \mathrm{j}$ du même aliment), les animaux maintiennent une glycémie constante mais les concentrations de lactate et d'alanine sont réduites tandis que les concentrations en acides gras sont accrues.

Si les concentrations plasmatiques de glucagon apparaissent peu affectées par les conditions physiologiques ou nutritionnelles, I'insulinémie diminue progressivement au cours de la gestation.

Ces données sont discutées afin de préciser certains aspects de l'adaptation du métabolisme chez la truie en fin de gestation.

\section{Références}

ANDERSON L. L., DUNSETH D. W., 1978. Dietary restriction and ovarian steroids on fetal development in the pig. Am. J. Physiol., 234, E190-E196.

ATINMO T., POND W. G., BARNES R. H., 1974. Effect of dietary energy vs protein restriction on blood constituents and reproductive performance in swine. J. Nutr., 104, 1033-1040.

AYNSLEY-GREEN A., BIEBUYCK J. F., ALBERTI K. G. M. M., 1973. Anaesthesia and insulin secretion: the effects of diethyl ether, halothane, pentobarbitone sodium and ketamine hydrochloride on intravenous glucose tolerance and insulin secretion in the rat. Diabetologia, 9, 274-281.

BATTAGLIA F. C., MESCHIA G., 1978. Principal substrates of fetal metabolism. Physiol. Rev., 58, 499-527. 
BERGMEYER H. U., 1974. In Methods of enzymatic analysis, 2nd edn (translated from the 3rd German edn), Acad. Press, New York.

CLOSE W. H., NOBLET J., HEAVENS R. P., 1985. Studies on the energy metabolism of the pregnant sow. 2. The partition and utilization of metabolizable energy intake in pregnant and non-pregnant animals. Brit. J. Nutr., 53, 267-279.

DE WILDE R. O., 1980a. Protein and energy retentions in pregnant and non-pregnant gilts. I. Protein retention. Livest. Prod. Sci., 7, 497-504.

DE WILDE R. O., 1980b. Protein and energy retentions in pregnant and non-pregnant gilts. II. Energy retention. Livest. Prod. Sci., 7, 505-510.

DUÉE P. H., DESMOULIN B., ETIENNE M., DURAND G., 1983. Effets d'une réduction de l'apport protéique durant la gestation sur le métabolisme maternel et l'évolution de la composition corporelle au cours du cycle de reproduction chez la truie. Ann. Zootech., 32, 21-42.

ELSLEY F. W. H., ANDERSON D. M., McDONALD I,, Mac PHERSON R. M., SMART R., 1966. A comparison of the live-weight changes, nitrogen retention and carcass composition of pregnant and non-pregnant gilts. Anim. Prod., 8, 391-400.

ETIENNE M., 1979. Influence de l'alimentation des truies gravides sur l'évolution des réserves corporelles maternelles et le développement de la portée. Ann. Biol. anim. Bioch. Biophys., 19, 289-302.

FRIEND D. W., 1971. Self-selection of feeds and water by swine during pregnancy and lactation. J. anim. Sci, 32, 658-666.

GEORGE P. B., ENGLAND D. C., SIERS D. G., STANTON H. C., 1978. Diabetogenic effects of pregnancy in sows on plasma glucose and insulin release. J. anim. Sci, 46, 1694-1700.

GILBERT M., HAY W. W., JOHNSON R. L., BATTAGLIA F. C., 1984. Some aspects of maternal metabolism throughout pregnancy in the conscious rabbit. Pediatr. Res., 18, 854-859.

GILBERT M., PÉGORIER J. P., 1981. Substrate concentration changes during pregnancy in the conscious rat. J. dev. Physiol., 3, 343-354.

GIRARD J. R., CUENDET G. S., MARLISS E. B., KERVRAN A., RIEUTORT M., ASSAN R., 1973. Fuels, hormones and liver metabolism at term and during the early postnatal period in the rat. J. clin. Inv., 52, 3190-3200.

GÖSCHKE H., BÄR E., GIRARD J., LEUTENEGGER A., NIEDERER W., OBERHOLZER M., WOLFF G., 1978. Glucagon, insulin, cortisol, and growth hormone levels following major surgery: their relationship to glucose and free fatty acid elevations. Horm. Metab. Res., 10. 465-470.

HALTER J. B., PFLUG A. E., 1980. Effects of anesthesia and surgical stress on insulin secretion in man. Metabolism, 29, 1124-1127.

HEAP F. C., LODGE G. A., 1967. Changes in body composition of the sow during pregnancy. Anim. Prod., 9, 237-245.

HO R. J., 1970. Radiochemical assay of long chain fatty acids using ${ }^{63} \mathrm{Ni}$ as tracer. Analyt. Biochem., 36, 105-114.

KALKHOFF R. K., KISSEBAH A. H., KIM H. J., 1978. Carbohydrate and lipid metabolism during normal pregnancy : relationship to gestational hormone action. Semin. Perinatal, 2, 291-307.

LETURQUe A., BURNOL A. F., FERRE P., GIRARD J., 1984. Pregnancy-induced insulin resistance in the rat : assessment by glucose clamp technique. Am. J. Physiol., 246, E25-E31.

LODGE G. A., FRIEND D. W., WOLYNETZ M. S., 1979. Effect of pregnancy on body composition and energy balance of the gilt. Can. J. anim. Sci., 59, 51-61.

O'KEEFE S. J. D., SENDER P. M., JAMES W. P. T., 1974. "Catabolic » loss of body nitrogen in response to surgery, Lancet, $n^{\circ} 7888,1035-1038$.

PÉGORIER J. P., DUÉE P. H., GIRARD J., PERET J., 1983. Metabolic fate of non-esterified fatty acids in isolated hepatocytes from newborn and young pigs. Evidence for a limited capacity for oxidation and increased capacity for esterification. Biochem. J., 212, 93-97.

PHELPS R. L., METZGER B. E., FREINKEL N., 1981. Carbohydrate metabolism in pregnancy. XVII. Diurnal profiles of plasma glucose, insulin, free fatty acids, triglycerides, cholesterol, and individual amino acids in late normal pregnancy. Am. J. Obstet. Gynecol., 140, 730-736.

RÉRAT A., 1982. Absorption des sucres et des acides aminés chez le porc, 63-85. In LAPLACE J. P., CORRING T., RÉRAT A., Physiologie digestive chez le porc. Les Colloques de I'I.N.R.A., $\mathrm{n}^{\circ} 12$. 
RERAT A., VAISSADE P., VAUgelade P., ROBIN D., ROBIN P., JUNG J., 1977. Determination of nature and quantity of endogenous nitrogen absorbed during the digestion of a protein-free meal in the pig. Vth int. Symp. on Amino Acids, Budapest.

RUIZ M. E., EWAN R. C., SPEER V. C., 1971. Serum metabolites of pregnant and hysterectomized gilts fed two levels of energy. J. anim. Sci., 32, 1153-1159.

SALMON-LEGAGNEUR E., 1965. Quelques aspects des relations nutritionnelles entre la gestation et la lactation chez la truie. Ann. Zootech., 14 (n ${ }^{\circ}$ 1, H. S.), 1-137.

SHIELDS R. G., MAHAN D. C., 1983. Effects of pregnancy and lactation on the body composition of first-litter female swine. J. anim. Sci, 57, 594-603.

SPARKS J. W., PEGORIER J. P., GIRARD J., BATTAGLIA F. C., 1981. Substrate concentration changes during pregnancy in the guinea pig studied under unstressed steady state conditions. Pediatr. Res., 15, 1340-1344.

WANGSNESS P. J., ACKER W. A., BURDETTE J. H., KRABILL L. F., VASILATOS R., 1981. Effect of fasting on hormones and metabolites in plasma of fast-growing, lean and slowgrowing obese pigs. J. anim. Sci., 52, 69-74.

YANG R. D., MATTHEWS D. E., BIER D. M., WEN Z. M., YOUNG V. R., 1986. Response of alanine metabolism in humans to manipulation of dietary protein and energy intakes. $A m$. J. Physiol., 250, E39-E46. 